Prof. dr. Remzija Hadžiefendić-Parić

\title{
POETIKA BOŠNJAČKIH NARODNIH USPAVANKI ${ }^{1}$
}

\section{Sažetak}

Riječ je o tradicionalno njegovanom usmenom književnom žanru bošnjačke književnosti - kantabilnom, pjevno izvođenom u svom stvarnom funkcioniranju kao, uostalom, $i$ druge usmene pjesničke vrste (npr. sevdalinke). Uspavanka je, prema tome, dvostruko kodirana: ima svoj ,libreto“ (tekst koji pripada književnoumjetničkom kodu) i izvedbu/učenje (napjev - koji pripada muzičkom kodu i uključuje raznovrsna ponavljanja, često gubljena iz vida pri zapisivanju uspavanke). Naša analiza tiče se prvog plana $i$ postupaka... Uspavanka je, po pravilu, govor majke sinu (,,pa se majka /sa/ sinom razgovara") ili šire - ženski govor, budući da su je uglavnom izvodile žene. Majka/žena govori sebe, pa se is tog aspekta uspavanke i posmatraju.

Ključne riječi: uspavanka, narodna/usmena knj., alhamijado knj., lirska pjesma, govorni čin, direktiv, preregistracija, ženski govor, žensko pismo, figure ponavljanja.

\section{Uspavanka-pjesma uspavljivanja}

Riječ, kao što znamo, prati čovjeka kroz cijeli život. U onim graničnim trenucima našeg života, kojima pripada rođenje (kao i smrt), riječ ima posebno važnu ulogu, prigodna je i ritualna. Takva je pri nadivanju imena djetetu kao govornom činu posebne vrste - tipa

\footnotetext{
1 Analize smo zasnovali uglavnom na izborimu bošnjačkih uspavanki koje su priredile Jasmina Musabegović („Bošnjačke uspavanke“, Sarajevo, 1997; notograf Vinko Krajtman) i Nirhe Efendić (,San u bešu, uroci pod bešu“, Sarajevo, 2007), u daljem tekstu „Bošnjačke...“ i „San...“. U njima su, kako napominju, uglavnom uspavanke ranije objavljene u zbirci Cvjetka Rihtmana „Dječije pjesme“, čiji je izdavač ANBiH, 1974. Ostali izvori - vidjeti: Izvori, na kraju rada.
} 
deklarativa (samim izgovaranjem obavlja ono što označava) ${ }^{2}$, koji je u isto vrijeme jedan vjerski obred. Takva je i u situacijama uspavljivanja djeteta - u nježnom, emotivnom govornom činu tzv. direktivnog tipa (želi se utjecati na ponašanje onoga kome je upućen) ${ }^{3}$, mjerljovom pak učinkom koji ostvaruje a to je uspavljivanje.

Naime, ranu fazu ljudskog života nježno zavijenu vilinim povojem $\mathrm{u}$ tradicionalnim kulturama obilježava posebna vrsta govornog čina u kojem se, kako govori jedna uspavanka, majka /sa/ sinom razgovara. Običaj je da se dijete uspavljuje u intimi pobožne tišine pjevušenjem/učenjem stihova usporenog ritma i posebne intonacije, melodije i tona, čak često posebno tembrirani... Tako, kao drevna lirska pjesma ${ }^{4}$, na početku čovjekva života stoji uspavanka (u bos., hrv., srp., slov. uspavanka prema radnji, tj. gl. uspavati, kao i engl. lullaby, od to lull 'uspavati'; rus. kolybelnie pesni prema predmetu, tj. od kolybel 'kolijevka', 'bešika', kao i u češ. ukolebavka od kolebka 'kolijevka').

Čini se da smo o uspavanki upravo rekli najbitnije: kad se pjeva, kako, kome i ko je, po pravilu, pjeva.

\section{2. Žensko pismo}

Običaji su, kako to etnologija tumači, način (sredstvo) komuniciranja među ljudima, s vlastitim pravilima $i$ predlošcima te /... kao takvi prenose poruke unutar i izvan skupine ljudi pa ih možemo posmatrati $i$ kao komunikacijski sustav (sustav prenošenja poruka) neke zajednice prema van $i$ njezinih članova među sobom (Weber-Kellermann). Kad su u pitanju bošnjačke uspavanke, riječ je o običaju (vrlo praktičnog cilja) neobično njegovanom na cijeloj bh.

${ }^{2}$ V.: Traugott E.C. i Pratt, M.L., „Linguistics for Students of Conversational of Literature“, New Your, 1980, u: Branka Novosel, „Prevođenje kroz prizmu lingvistike teksta i pragmalingvistikčkih spoznaja“, Prevoditelj, br. 80-81, HDZIP, 2004. Govorni čin je minimalna jedinica jezičke komunikacije, nužno situiran, kontekstualiziran - kontekstno uključen (up.: W. Iser, „Der Akt...“, Munchen, 1976). Bitno je ne izubiti iz vida i sljedeće: da bi neki iskaz bio npr. deklarativ i sl., moraju se ispuniti tzv. uvjeti uspješnosti (felicity conditions).

${ }^{3}$ Up.: B. Novosel, „Prevođenje...“, Prevoditelj, HDZIP, Zagreb, 2004, 60-61.

${ }^{4}$ Istraživanja su utvrdila da u djetetovom životu od 4. do 10 . mjeseca čak $40 \%$ prevladava poetski izraz, up.: I. Škarić, „Nastanak dječjeg govora“, Zavod za fonetiku, Zagreb, 1974. 
teritoriji $^{5}$ kako je to još prije jednog stoljeća primijetio A. Hangi u knjizi „Die Moslim's in Bosnien - Hercegovina“ (1907), odakle je i ova uspavanka:

Majki d'jete u ruži se našló.

Ružica ga na list dočekala,

B'jela vila u svilu povila.

A pčelica medom zadojila,

Lastavica krilom pokrivala;

Nek' je rumen ko ruža rumena,

Nek' je bijel ko bijela vila,

Nek'je radin ko pčela malena,

Nek je hitar kano lastavica. (Hangi 1907:245)7

Najčešće $\mathrm{u}$ intimi zatvorenog prostora, nerijetko $\mathrm{u}$ prirodi $(\mathrm{u}$ bašči ili na polju gdje se radilo), majka, nana ${ }^{8}$ ili tetka (najčešće materina seka) - po pravilu dakle žena ${ }^{9}$ - uspavljivala je dijete u

${ }^{5}$ Sarajevo, Banja Luka, Mostar, Jajce, Srebrenica, Hlivno, Gradačac, Zenica, Prozor, Orašje, Nemila, Cazin, Vlasenica, Cazin, Zvornik, Kozarac, Hlivno, Prnjavor... mjesta su u kojima su zabilježene uspavanke u navedenim zbirkama J. Musabegović, „Bošnjačke...“, Preporod, Sarajevo, 1997. i N. Efendić, „San...“, BZK Preporod, Sarajevo, BZK Preporod, Vogošća, 2007.

${ }^{6}$ Glagol naći se u staroj bosanskoj frazi bezličnog oblika našlo se dijete znači: 'dobiti dijete', 'roditi dijete', up.: varijante naš'o mu se sin, našla mu se kćer.

7 Ovu uspavanku svrstanu među „obredne i običajne pesme“ nalazimo u knjizi Blagoja Ž. Živkovića „Uvođenje u književnost i pismenost“ (Kulturni centar, Novi Sad, 1969) u ovoj varijanti: Majka Jovu u ruži rodila/ ružica ga na list dočekala,/ bela vila u svilu povila,/ a pčelica medom zadojila, / lastavica krilom pokrivala, / nek' je rumen k'o ruža rumena, / nek' je bijel k'o bijela vila, / nek' je radin k'o pčela malena,/ nek' je hitar kao lastavic (str. 20).

Pod naslovom (prvog stiha) „Majka Smaju pod đulom rodila“ ova se uspavanka, s notnim zapisom, nalazi u zb. J. Musabegović, "Bošnjačke..." (str. 12); nalazimo je i u zb. N. Efendić , „San...“, pod istim naslovom (str. 22) a neke stihove i u uspavanki „Majka sina u gori rodila“ (str. 25).

${ }^{8}$ Nana (tur.) u bosanskom jeziku, kao što je poznato, osim što znači 'majka', znači isto što i nena, nene -'očeva ili materina mati' i ' stara žena' (v.: A. Škaljić, „Turcizmi u srpskohrvatskom jeziku, Svjetlost, Sarajevo, 1989. i Dž. Jahić, „Školski rječnik bosanskog jezika“, Ljiljan, Sarajevo, 1999).

9 Up. Musabegović, „Bošnjačke...“, Preporod, Sarajevo, 1997, str. 8. Iz istih, praktičnih razloga, beša je ljuljana nogama. U romanu u stihovima Envera Čolakovića „Jedinac“ (rukopis završen 1947) nalazimo stihove da otac, „muška 
šimiširovoj bešici, na rukama, u krilu ili na ispruženim nogama ( $d a$ majci budu slobodne ruke za drugi posao) ${ }^{10}$ pjevušeći (učeći) tihim glasom i polaganim ritmom lirsku pjesmu nježna pripjeva. Dijete je pri tome u takvom položaju tijela koji mu omogućuje da slobodno gleda uvis - na nebeski beskraj odakle stiže bogatstvo kosmičkih utisaka (Kurtene 1905) i kojemu su okrenuti dlanovi u molitvi. Horizont najčešće ispuni toplo lice hraniteljica i zaštitnice, tj .majke.

Dijete je najčešće sin, a žena koja uspavljuje majka... (Čini se da je narodni genij napravio zanimljivu ravnotežu u usmenoj književnosti: majka pjeva uspavanku sinu u bešici, a kćeri će kasnije kao djevojci - momak pjevati sevdalinku pod pendžerom, kao što će momka/muškarca - gaziju - u prvi plan staviti junačka/epska pjesma, a djevojku/ženu lirska.)

U zabilježenim uspavankama majka se, po pravilu, ne obraća kćeri. (Istina, ni u baladi, u kojoj također iščitavamo poseban odnos majke i sina, majka nema nekog razumijevanja za kćer: npr. u posve delikatnoj situaciji, kad mlađahna Mejra naslućuje tragediju voljenog

glava“, ljulja sina i pjeva, uspavnake ko da je žena: U bešici spava jedinac, /nogom ga Tifan sve ljulja/ i pjevuši, ko da je žena. I „Spavaj sad, meleću moj, babo će opanke kupit/ zlatne ti, pa kad odrasteš/ s njima se po sijelima gizdaj... “ („Jedinac“, BNZH, Zagreb, 2005, str. 54) Da očevo ljuljanje djeteta nije Čolakovićeva „licentia poetica“, vjerujemo mogu mnogi posvjedočiti, pa i autorica ovog teksta iz svog djetinjstva nosi sliku svog oca kako joj ljulja brata Midhata u bešici.

${ }_{10}$ Musabegović, „Bošnjačke...“, 1997, str. 8. Iz istih, praktičnih razloga beša je ljuljana nogom. U „Jedincu“ Envera Čolakovića nalazimo sljedeći opis: „... u ruci pletivo drhti/ pod nogama bešika škripi/ u kojoj se Hajrica ljulja/ dok san s njime igra se žmire,/ varaka ga, zove, i draška, / pa opet s očiju bježi/ u kut sobe, gdje u limenoj peći/ pucketa ćarlijuć vatra... Igle međ prstima stale./ S čarapa otpalo okcel i noga pod priglavkom u grč/ stegla se, pa bešika natren/ ostala na lijevu stranu/ nagnuta, ko čamac na valu.../ San u igri uštinuo Hajru/ za obraz, pa zaplaka dijete./ Opet oživje noga/ i zaškripuca beša,/ a s usana Mejrinih pjesma/ poteče ko planinski potok./'Spavaj, moj lijepi sine,/ probudit će smiješkom te babo/ i džidže međ prstiće ti stisnut'.../ Vrijeme klizi uz pletivo, igle / i čarapa raste; raste ko i noć./ Već davno Hajro zaspo. U mraku/ ruke same vide, jer ne vide oči,/ al ustat neće, jer je griska strah/ da korakom mekim ne probudi dijete.../ Pred očima pauk ispreo mrežu,/i Mejra sniva... U krilo joj sklizila / iz umornih prsta iskrivljena igla... “ („Jedinac“, BNZH, Zagreb, 2005, str. 133-5) J. Musabegović govori o ljuljanju djeteta na nagoma i u tome nalazi posebnu simboliku: taj položaj je i imitacija prvog izlaska djeteta na svijet, još potpuno neodvojenog od majčinog tijela, od njegove orbite i zavisnosti. Up. Musabegović, „Bošnjačke...“, Preporod, Sarajevo, 1997, str. 7. 
momka, njena će je majka oštro prekoriti: Muč, ne luduj, Merima djevojko,/ sad tvoj Omer drugu dragu ljubi,/ a za tebe mladu $i$ ne haje). Odsustvo ,ženskih“ uspavanki može se razumjeti kao bitno obilježje usmene uspavanke.

U patrijarharnoj porodici (bošnjačkoj tradiciji) pozicija kćeri i sina nije ista: sin je budući zaštitnik majke, njen skrbnik u starosti. (Kako ističe Hangi, čak i najsiromašnija mati svog sinčića nazivala je begom, agom, pašom..., što je djetetu ostajalo kao nadimak kasnije do kraja života.) Kći pak - kad odraste - udajom mijenja roditeljski prag, napušta raniji životni prostor, dobiva novo prezime, a na neki način i „novo“ ime: prema muževljevom imenu ili, ako je imao titulu ili zvanje, po njegovoj tituli, zvanju i sl. (Hasanaginica - Hasanagina žena, Ibrahimovca - Ibrahimova žena, kadinica ${ }^{11}$ - kadijina žena, hodžinca - hodžina žena), a nerjetko je nazivana mladom ('nevjesta', 'mladenka') - što je mogla nositi i kao starica, ako već nije bila došla mlađa, nova „mlada“ u porodicu.

\section{Majka i sin}

U bošnjačkoj usmenoj književnosti općenito iščitavamo poseban odnos majke i sina. Smještena u sferu privatnog, kao prostoru koji joj tradicionalno patrijarhalni svijet namjenjuje, majka je tako $\mathrm{u}$ baladama često domaćin kuće, starješina patrijarhalne porodice, dok je muž zauzet muškim poslovima (Nazečić 1998:143). Ona je čuvar porodičnog gnijezda i patrijarhalnih vrijednosti, čuvar tradicije (Nazečić 1998:143) Veličina narodnog genija u tome je što ju je imao hrabrosti i snage oštro osuditi kad je postajala provoditelj neprihvatljivih patrijarhalnih načela jedne sredine, zapravo osuditi takvu sredinu i njen nakaradni moral. Pa kad voljenom sinu na silu nametne nepravične kriterije u pitanjima duše i srca (Ljepšom će te

${ }^{11} \mathrm{U}$ „Dervišu i smrti“ M. Selimovića pojavljuju se npr. kadinica i spahinica, ženski likovi upravo imenovani na taj način - titulom supruga, tj. obezimenjene. Pripadaju hijerarhijskoj ljestvici visoko pozicioniranih u romanu, za razliku npr. od Zejne, junakinje društveno nisko pozicionirane, koja je pak imenovana ličnim imenom. O načinu imenovanja likova vezano za mjesto na društvenoj ljestvici v. u našim radovima: „Turcizmi u funkciji imenovanja likova u Dervišu i smrti i $\mathrm{Na}$ Drini ćuprija“ (, Književni jezik“, XIII, br. 4, Sarajevo, 1984) i „Imenovanje likova turcizmima u Dervišu i smrti“ („Radovi Filozofskog fakulteta u Sarajevo, knj. XI, Sarajevo, 1990). 
oženiti majka...,/ Još je Fata od roda bogata,/ i tebe će potpomoći blagom...), narodni genij će pogubnost takvih moralnih načela pokazati npr. odvođenjem u smrt majci dobrog i poslušnog sina kao u baladi „Smrt Omera i Merime“. Omer se neprikosnovenoj majčinoj želji verbalno opirao, jedinim načinom koji mu je ostao na raspolaganju (Neću Fate za života svogal jer ja volim Merimu djevojku./ Nije blago ni srebro ni zlato/ već je blago što je srcu drago!). Iskrivljena načela (prednost ljepoti i bogatstvu nad ljubavi), čiji je nositelj u baladi majka, pokazat će narodni genij, uništavaju sreću vlastite djece (v. Nazečić 1998:143). U uspavankama pak odnos majke i sina drukčiji je već time što je riječ o posve različitom žanru usmenog diskursa.

Direktno obraćanje bitan je postupak uspavanke kao emotivno angažiranog govorenja/pjevanja (up.Vuletić 1986:17) a jezik u njoj ima, osim izrazito emotivne (ekspresivne), konativnu funkciju upravo zato što je sva orijentirana prema djetetu kao recipijentu (adresatu). Dijete je Mujo, Smajo, Aljo, Ale, Ibro, Anija, Kemo, sin - po pravilu „muška glava“. Majka se $s^{\prime}$ sinom razgovara (uz odsustvo lične zamjenice u prvom licu: nikad neće reći "ja sam Smaju..." , nego toplo i prisno s pozicije približene djetetu, odnosno izjednačene $\mathrm{s}$ pozicijom djeteta: „majka Smaju...“, što je pak pitanje tačke gledišta na frazeološkom, psihološkom i ideološkom planu, v.: Uspenski 1979) oslovjavajući ga:

(A) vlastitim imenom u prisnoj hipokorističnoj formi, riječima odmila (često u vokativu):

-Spavaj, Kemo, tebe majka ljulja (,San...“, 36)

-Rabbum Allah, Ti mi daj, mome Muji dug zeman... (,Vjerski običaji...“, 185) -Majka Smaju pod đulom rodila... (,San...“, 22)

(B) zajedničkom imenicom sin:

(B1) u vokativu - uz gramatičke oblike (glagola, pridjeva, zamjenica) u muškom rodu koji ,,potvrđuju“ (mušku) spolnost djeteta (sam zaspi, veći narasti, moj sine, nek je lijep, nek je radin...):

-Lila, sine, san te prevario,

Sam mi zaspi, pa veći narasti... („Bošnjaci...“, 16)

-Nini, nini, moj sine jedini, 
Nini, nini, u džidžinoj beši... („Bošnjačke...“, 14).

-Ninaj, sine, u varakli beši /.../

Neka uči kano lastavica,

Nek je lijep kano b'jela vila,

Nek je radin kao mala pčela... (,San...“, 21)

(B2) u vokativu - bez drugih pokazatelja roda/spola, pa je imenica sin jedini nositelj obilježja roda, odnosno spola:

-Spavaj, sine, san te prevario,

Beša ti se na moru kovala... (,Bošnjačke...“, 46)

-Ninu, sine, san te prevario... („Bošnjačke...“, 44)

-Spavaj, sine, rasti spavajući,

Vel'ko dobro, majku gledajući.

San te vara, sreća te ne vara... (,San...“, 19)

-Spavaj, sine, od đula ti beša /.../

Pri čem vidi dite posisati... (,San...“,43)

(B3) bez direktnog obraćanja i oslovljavanja (imenica $\sin$ nije u vokativu, već u dativu, akuzativu...) - uz gramatičke pokazatelje (muškog) roda/spola (npr. zamjenicom ga, mu...):

-Majka sina $u$ gori rodila /.../

Gorica ga na list dočekala

Bila vila sinu eba bila... (,San....", 25)

-Majka sina u ruži rodila,

Ružica ga na list dočekala... („San...“, 49)

-Majka sinu tanku košu kroji...

koja mu je pupak urezala... (,San...“, 44)

(C) bez direktnog obraćanja i oslovljavanja (i imenice sin), uz glagole u gramatičkim formama muškog roda, koji signaliziraju $\mathrm{rod} / \mathrm{spol}$ (radni gl. pridjev ostario):

-Nina, buba, ostario majci,

Ostario i ocu i majci... (,Bošnjačke...“,18)

(D) Ima određen broj uspavanki koje su bez direktnog obraćanja ličnim imenom i sl., i bez gramatičkih formi koje bi mogle 
signalizirati da je u pitanju sin, a ne kći, pa su se, kao takve, mogle bez naknadnog ,prekodiranja“ (tj. supstitucije imena i prilagođavanja gramatičkog roda spolu) pjevati i kćeri i sinu, npr.:

-Nini, nini, ko u svojoj beši!

Tvoja beša na moru kovana,

Kovale je age $i$ hadžije... (,San....", 24)

-Alalh, Allah, la ilahe ilellah.

Nini, nini, ninala te majka,

Ninala te i uspavala te... (,San...", 34)

-Majka tebe u šumi rodilla,

Ušumici ovce čuvajući.

Bila vila tebi eba bila... (,, San...“, 46),

-Nini, bubi, ponikli ti zubi,

Kovala je tri dobra kovača... (,Bošnjačke...“, 48)

(E) $\mathrm{Na}$ isti su način, tj. podjednako kćeri i sinu, upućivane uspavanke s oznakom „minus spol“ u kojima je dijete (najčešće nježnom i toplom metaforom) imenovano imenicom ,spolno neobilježenog", neutralnog srednjeg roda (janje, zlato, čedo):

-Ninaj, bubaj, u ninanoj beši!

Tvoja beša zlatom okovana /.../

da s' ogleda moje janje malo... (,San...", 50)

-Nina, nina, milo janje,

De ti spavj majke svoje,

Spavaj, spavaj, janja moje,

Dok zorica ne osvane... (,San...“, 42)

-Nina,nina, janje malo,

janje malo u travi zaspalo;

pokrilo se ditelinom travom... (,,San...“, 35)

-Spavaj, spavaj, čedo prenejako,

Uspavaj se u šimšir bešici...(,,San...“, 33)

-Spavaj, zlato, san te prevario...(,, San...",38)

Istina, i neke su se uspavanke s obraćanjem djetetu imenicom m. roda sine (B2) mogle upućivati ženskom djetetu (kao i one pod D i E), budući da je takav običaj obraćanja djetetu obaju spolova bio 
običan, a i danas živo prisutan u razgovornom jeziku ${ }^{12}$. Istina, u takvim upotrebama riječ sin funkcionira kao neka vrsta poštapalice, „ispražnjena“ i od sadržaja 'spol' i od sadržaja 'najbliži srodnik muškog roda narednog pokoljenja' (i akcent joj je nešto skraćen, usp. izgovor: /dođi_sine/ i /dođisine/). Zato se i naredna uspavanka mogla podjednako lahko pjevušiti/učiti sinu kao i kćerkici u bešici, tim prije što se u njoj pojavljuje i stilistički neutralan oblik srednjeg roda (ikavski oblik dite - s općim značenjem 'dijete', bez obzira na spol):

-Spavaj, sine, od đula ti beša,

Tvoja beša na moru građena,

gradile je do tri kujundžije:

Jedan kuje, drugi pozlaćuje,

Treći gradi od zlata jabuku,

Ujabuci alem, kamen dragi,

Pri čem vidi dite posisati,

U po noći kano i u podne.“" (,San...“, 43)

I u ranije navedenoj uspavanki koju je Hangi zabilježio, premda se uspavljuje d'jete (Majki d'jete u ruži se našlo), u drugoj strofi stoji: nek je rumen...(a ne 'rumeno', kako bi se moglo očekivati po uvodnom, prvom stihu). Upotrebom muškog roda izbjegnuto je moguće povećanje broja slogova, koje bi narušilo deseteračku shemu (usp. varijantu iste uspavanke „Majci kćerka u ruži se našla..."). Postupak u kojem je kombinacija srednji rod (d'jete) plus muški rod

${ }^{12}$ Up. sinak u pričanju, obraćanju sl., v. : Dževad Jahić, „Školski rječnik bosanskog jezika“, Ljiljan, Sarajevo, 1999. Slično može funkcionirati i druge riječ, npr. brat, up.: Falio se Carigrđanin /.../Ču ga Sarajlija, pa će ope': 'Jok brate, nema kasabe..., v.: Đenana Buturović, Lada Buturović: „Antologija usmene priče iz BiH“, Svjetlost, Sarajevo, 1997,193. Muški rod je u odnosu na ženski općijeg značenja, pa se neke imenice muškog roda ( $u$ značenju zanimanja, profesije i sl.) - budući da je m. rod neobilježen, nemarkiran (unmarked) - mogu upotrijebiti i kad je riječ o osobama ženskog spola. Zato možemo reći: On/Ona je profesor., ali samo Ona je profesorica. I. Klajan je pisao: „Među imenicama sa značenjem ljudi i životinja gramatički ženski rod je uslovljen prirodnim, dok za muški to ograničenje ne važi. Otuda imamo sufikse za izvođenje feminina iz masuklina, a gotovo nikad obrnuto (lav lavica, ital. leone - leonessa, šp. doctor - doctora), upotrebu muških imenica za ženska bića /.../“. U tom kontekstu I. Klajn navodi zaključak Hallidaya i Hasana „da je muški rod the syntactically unmarked form.“ (v.: I. Klajn, „Funkcija i priroda zamjenica“", Institut za srpskohrvatski jezik, Beograd, 1985, 90) 
(rumen) implicirao značenje 'nežensko' signalizira da navedenu uspavanka ipak razumijevamo prije kao obraćanje sinu nego kćeri.

U određenom broju uspavanki, čak i onda kad nije eksplicite iskazano da je riječ o sinu, postoje jezički pokazatelji koji na to ukazuju, npr.:

(F) značenje (sadržaj) riječi oženiti (anticipira spol jer muško se ženi, a žensko udaje):

-Ala, lila, mati te rodila

Ala, lila, mati te imala,

Imala te i nahranila te,

Ako bog da $i$ oženila te. („Bošnjačke...“, 52)

Zaninljivo je da nismo naišli na usmenu uspavanku kojom se eksplicite uspavljuje kćer: nismo našli ni jednu uspavanku sa ženskim imenom. Ne mislimo, dakako, da bi trebalo zaključiti kako se curicama nisu pjevale/učile (iste) uspavanke. U govornim događajima ovakve vrste - kao i u situacijama prilagođavanja i variranja muškog ličnog imena (po pravilu hipokoristčnog oblika) - majke/žene su čin uspavljivanja rodno/spolno improvizirale, prilagođavale na licu mjesta. Potvrdu za to našli smo u jednoj rukopisnoj uspavanki ${ }^{13}$, posve sličnoj Hangijevoj (ponovno uvjereni da je historija uvijek u konačnici samo tekst!). U njoj se majka obraća - kćeri. (Život ipak piše - uspavanke!) Prvi stih ovako započinje:

Majci kćerka u ruži se našla...,

pa su i oblici u narednim stihovima u (ili prilagođeni) ženskom gramatičkom rodu:

nek' je rumena ko ruža rumena...

Navedeni stih narušava metričku shemu pjesme: umjesto uobičajenog deseterca $\mathrm{s}$ cezurom poslije četvrtog sloga $(4+6)$, neočekivano imamo jedanaesterac s pomaknutom cezurom (5+6), što možemo tumačiti kao signal da je (ipak) u pitanju samo (ženska)

${ }^{13}$ Riječ je o rukopisu jedne uspavanke. Uspavanku smo posve slučajno pronašli ostavljenu u knjizi A. Hangija, posuđenoj od gđe Emine Fazlagić (r. u Sarajevu). 
varijanta Hangijeve uspavanke. (Uz to $\mathrm{u}$ prvom stihu imamo standardizirani dativ majci sa silabiziranim suglasnikom $c$ - što se također može uzeti kao potvrda da je riječ o mlađoj verziji.)

Uspavanka pokazuje da su, premda ih uglavnom i ne nalazimo zabilježene u toj varijanti, mnoge ,muške“ uspavanke, uglavnom zabilježene kao takve, lahko bivale prekodirane u ,ženske“ u svom stvarnom funkcioniranju...

\section{Riječ je u (posjedu) majke}

Možda će se moći zaključiti da se opet, u kulturi dugo njegovane ženske pasivnosti i istiskivanja tijela iz javnog života, $\mathrm{u}$ kulturi ljepote naslućivanja i nedorečenosti, ipak ,priča vrti oko muškog roda“ a žena svodi na jednu dimenziju - majčinstvo. U uspavankama majka je apsolutno superiorna. U posjedu je izravne Riječi: ona je ta koja govori, dakle ,poizvodi“ i odašilje jedan emotivni tekst vrlo naglašene subjektivnosti i etičnosti.

$\mathrm{U}$ poziciji je superiornog pošiljaoca (adresanta) poruke $\mathrm{u}$ odnosu na sina/dijete kojem upućuje imperative (spavi, spavaj, nini, lali, luli...) i prema kojemu ima određene zahtjeve (neka uči..., nek je radin...) na koje polaže pravo budući da je roditeljica, hraniteljica $i$ zaštitnica. Imperativi su, po pravilu, u posjedu dominantnih govornika u komunikaciji, kao što i zahtjeve postavlja onaj ko je na neki načen nadređen. Imperativi, koji proizilaze - kako ističe Jakobson (1966:292) - iz orijentacije prema recipijentu, ovdje su nježni, blagi i molećivi, izvedeni od onomatopejskih glagola i glagola posebnog značenjskog gnijezda (nini, bubi, spavi uz spavaj, zaspi, rasti, narasti...), a zahtjevi pak dolaze kao zahvalnost harmoniji prirodnog reda, u koji je dijete zaštitnički i prijateljski primljeno, s implicitnom opomenom da toj harmoniji i redu Svevišnjeg, Univerzumu, i ono samo pripada (gorica ga na list dočekala; liskov prutak povoj ti je bio; liskov listak pelena ti bila; pokrilo se ditelinom travom; košutice košulje krojile, a povoji zelena kupina, pelenica djetelina trava; lastavica ezan proučila; pčelica medom zadijila; golubica na babine došla...).

Međutim, majka se u isto vrijeme nalazi i u jednoj inferiornoj poziciji: molbama se obraća Svevišnjem i bogobojazno traži blagoslov (dragi Bože, Ti mi daj..., Rabum Allah, Ti mi daj...). Svoju poziciju (želje) ona će ovdje izjednačiti s pozicijom (željom) djeteta. Naime, 
moli, traži blagoslov, istina imperativima (daj), pa enklitičkim objektnim dativom $(\mathrm{mi})$ pokazuje da je to pozicija jednog posesivnog govornika (daj mi: daj meni) - da bi sljedećim stihom otkrila da zapravo to što moli i traži, moli i traži za svoga sina/dijete posredno ga tako štiteći: $t i$ mi daj, mome sinu... Ljubav (dijete je $u$ želji rodila) i pozicija hraniteljice daju joj pravo izjednačavanja dviju pozicija i da od Svevišnjeg traži i očekuje zaštitu (djeteta) kroz cijeli život (dijete to još nije u stanju):

-Rabum Allah, Ti mi daj, mome Muji dug zeman, da mi uči i klanja i u u mekteb uziđe... ( „Vjerski običaji...“, 185)

Isprepliću se tako u jakim pozicijama teksta (na početku i na kraju) citati (intekst) na arapskom s riječima bosanskog jezika dobivajući snagu hamajlije, spontane molitve (Kristeva 1979:214), dove $^{14}$. Na neki način očuđeni, kur'anski fragmenti na arapskom jeziku dobivaju zaštitničku funkciju, snagu i moć magičnih riječi kakvu nalazimo u nekim drugim usmenim žanrovima (npr. u bajkama).

Može se govoriti o a) pojedinim riječima preuzetim iz religijskog diskursa koje doprinose dokidanju, „brisanju“ granica diskursa (tako je lastavica ezan proučila, djeca idu Kevser-vodi,/ da zafate hladne vode.../ u ruci im maštrafice,/ pod pauzom sufarice, Ibro je do podne... hatmu izučio,/ a od podne ćitab hamajliju, sin je do četvrte u mekteb poš'o/ a do pete hatmu učinio...) i b) o doslovnom citatu, intekstu, kao dijelu ,zgusnutog““ i naglašenog religijskog diskursa obično u graničnim stihovima uspavanki (uvodnim i završnim) - koji je jezički jasno očuđen jer ne pripada kodu bosanskog, već arapskog jezika. Gotovo kao literarni ornament, preuzet iz Kur'ana časnog i preregistriran u uspavanki kao književnoumjetničkom tekstu čuvajući arhaično vjerovanje u moć magije riječi, takav (citatni, intekstni) dio dobiva funkciju jakog argumenta: zaštite djeteta od uroka, čuvara djetetova zdravlja, garancije lijepe budućnosti, dugog života... Pri tome se ne može

\footnotetext{
${ }^{14}$ Uspavanke su u bošnjačkoj tradiciji imale vrijednost dove, govorilo se: proučiti dovu prije spavanja u značenju 'uspavati dijete' (up.: I. Kajan, „Pod beharom moje janje spava“, Preporod, Zagreb, 1996).
} 
zanemariti nesumnjiva estetska funkcija takvog inkorporiranog dijela - njegova milozvučnost, efekat asonanci i aliteracija, ritmičnost itd., up.:

-Svakome će edžel doći,

i insanku i hajvanku,

i tičici u gorici,

i ribici u vodici,

crnu mravu na zemljici.

U kabur nas zatvoriti.

U kaburu mračna noćca,

ni pendžera ni hajata.

Oklen će nam voda teći?

Oklen će nam sunce sjati?

La ilahe illallah,

Muhammed Hak Resulullah. (,San...“, 51)

Završna dva stiha su, kao metatekstni segmenti, uključeni u govor majke: ona ih uči nad bešikom (La ilahe illallah...- 'Samo je jedan Bog') pjevušeći uspavanku i u isto vrijeme iskazuje odanost Svevišnjem moleći za ostvarenje svojih želja sinu/djetetu (Rabbum Allah, Ti mi daj/mome Ali dug zeman - 'Gospodaru Bože'...).

Neizmjerna ljubav prema sinu/djetetu ( $u$ želji rodila...), pozicija majke - rodilje, hraniteljice i zaštiutnice - i odanost Svemogućem (La ilahe illallah....) podloga su na kojoj gradi pravo izjednačavanja svojih sa sinovljevim željama čak i onda kad dijete odraste, kao Omer u poznatoj baladi. (Kad se zasnivaju na nepravičnim, neporalnim načelima, narodni genij će ih osuditi pokazujući njihovu pogubnost, kao u „Smrti Omera i Merime“ npr.).

Majčine želje i molbe upućene Svevišnjem imaju snagu blagoslova, emocije suprotne kletvi. Kletva, naime, kao deklarativni čin u usmenoj književnosti doslovno „ima snagu dogođenog“ (v. Krnjević 1998:248), up. baladu „Materina kletva“:

Uz bešu joj pismu zapivala:

"Nini, Ajko, odnili te vrazi!"

Punu vjetar s visokih planina,

Majka Ajku u bešici ljulja,

Pa odnese od olova kulu 
I u kuli plemenitu Ajku.

Ode kula prahu i pepelu,

Ode Ajka jadu i čemeru. (Kurt 1902: 66)

Majci neće biti teško dirljivo otkriti svoje ideale i neskrivene želje pronađene u prijateljski naklonjenoj prirodi, u bajkovitom svijetu trava $i$ cvijeća, pčelica $i$ lastavica, tičica $i$ ribica, vila $i$ nebrojena blaga: da joj sin bude zdrav i rumen (kao ruža), lijep (kao bijela vila), učevan (kano lastavica), radin (kano mala čela) i da joj jednog dana bude zaštita u starosti (tebe sebi za odgojka hrani), da joj hatmu prouči, da je mrtvim pokloni ${ }^{15}$ jer svijet je prolazan:

- Ovaj svijet bijeli cvijet,

ovaj insan bijeli behar.

I behar će opadati

i insan će pomrijeti.

Svakome će edžel doći...(,San...", 51)

U razdoblju života u kojem je sin dijete u beši, majka je nužno zaštitnica. Štiti sina/dijete od moćnih sila uroka i nesana u nemoći djeteta da samo sebe zaštiti. Uroci se tjeraju (uroke ti voda odnijela,/ za golemo brdo zanijela) zbog djetetove (urokljive) ljepote koja se ne opisuje, već naslućuje kroz želju (nek je lijep kao b'jela vila ${ }^{16}$ ). Naime, postoji u narodu vjerovanje da se izgovaranjem riječi ,ljepota“, „lijepo“ metonimijski otkriva moćnim uročnim silama jer „kao da izgovorene riječi čine ljepotu određenom, a ne samo prisustvo ljepote“ (Krnjević 1998:241).

Tjerajući uroke od djeteta, majka mu priziva sladak san i pjevuši svoje vlastite želje: da mi uči i klanja/ $i$ u mekteb uzide/ da mi hatmu proučil da je mrtvim pokloni... (,„Vjerski običaji...“, 185). Na svemu tome ona će gradi autoritet u životu svoga sina.

Ima jedna uspavanka iz Orašja J. Musabegović (str. 22) za koju je upravo dobro što ju dijete u uzrastu u kojem se uspavljuje zapravo i

\footnotetext{
${ }^{15}$ Vjerovatno je najdirljiviji i najsnažniji poetski „odgovor“ majci u umjetničkoj književnosti dao Skender Kulenović poemom „Na pravi put sam ti, majko, iziš,o“ i sonetom „Nad mrtvom majkom“.

${ }^{16}$ U baladama se može naći stih da „ljepota sama sa sebe strada“ (Hanifa Krnjević, „Urok, kletva i snoviđenje u baladi“", 1998, str. 240).
} 
ne razumije jer bi inače izazvala posve drugi efekt od onog koji se od uspavanke očekuje, unatoč ninanjima: Nini, nini... Ona nije „proizvedena“ iz pozicije majke: uspavljivač(ica) se djetetu obraća riječima bratiću moj mali. To je pozicija koja bi mogla pripadati, ako se prihvati da je to govor žene, djetetovoj tetki, očevoj sestri: dijete je njoj bratić 'bratov sin'. Uspavanka se i tu potvrđuje kao monolog žene, ispovijed žene u intimi prostora u kojem je - zaštićena od drugih - slobodna iznijeti duboku intimu e da bi možda sebi olakšala, a drugog možebiti neopteretila... Takva pozicija ženi daje slobodu da kaže, tamo gdje je niko ne čuje i ne razumije (a da ipak ne priča sama sa sobom), ono što možda ne bi u nekoj drugoj prilici nikome i nikada. $\mathrm{Pa}$ kad se kaže da se u uspavanki majka s' sinom razgovara, onda se ima $\mathrm{u}$ vidu to da je riječ u njenom posjedu i da glagol razogovarati ovdje ne označava 'razmjenu govora', već ono što je sadržaj gl. 'razgaliti' ili frazema 'razgovoriti koga'.

\section{Otac - pozicija materijalnog skrbnika}

Ocu je namijenjena uloga materijalnog skrbnika: putuje po gradovima, nalazi bešu (za sina!), pažljivo je odabire i skupo plaća; bogato nagrađuje sina za učenje (babo daje nebrojeno blago,/ dajdže daje čohe nerezate,/ am'dže daju hata nejahata, v.: ,,San... “, 38)...

Djetetova bešika je iznimno lijepa, okovana zlatom s alem kamenom dragim, maksuz za sina/dijete kovana i iz daleke zemlje donesena (s mora, preko mnogih gradova); personificira očevu ljubav i skrb. Za nju, naime, djetetov babo ne žali blago nebrojeno..., a sve to upravo da bi se naglasila veličina očinske ljubavi. Raskošna ljepota $i$ skupocjenost bešike, kojoj estetska posebnost nije sebi svrhom, već da se majka vidi ogledati (nek $s^{\prime}$ ogleda Alijina majka) i dijete podojiti usred noći kano usred dana..., dekonstruira se i kao suprugov dar v'jernoj drugi, djetetovoj majci, kao izraz njegove ljubavi. Raskošna ljepota i skupocijenost bešike nije samo u funkciji poetskog uvjeravanja djeteta u to koliko je željeno.

U uspavankama majka kara 'ruži' sina, čak je ona ta koja sina i bije i kara (i opet se s njime razgovara), a otac onaj koji ga brani:

- Nije Ibro na sokaku bio,

Već je Ibro u mejtef hodio,

U mejtefu djeci kalfa bio. 
Do podne je hatmu izučio,

A od podne ćitab hamajliju. („San...“, 26)

Takva pozicija podrazumijeva manje superiornog govornika $\mathrm{u}$ govornom činu. Kao da su u uspavankama zamijenjene uloge koje su tradicionalno (klišizirano) namijenjene ocu i majci: majka blaga, popustljiva i brani sina/dijete, a otac strog, nepopustljiv. U kontekstu uspavanke (uspavljivanja sina), očeve riječi dobivaju nešto drugačiji smisao. Njegova neizmjerna ljubav prema sinu trebala bi opravdati silne hiperbole kao očiglednu očinsku slabost i pristrasnost prema djetetu. Ismijavajući vlastitu neobjektivnost, otac brani sina svojim neprikrivenim pretjerivanjem koje graniči s fantastičnim. U odnosu na ulogu koja mu je $\mathrm{u}$ patrijarhalnoj porodici zadana, pozicija $\mathrm{u}$ uspavankama otkriva se kao njena svojevrsna iznevjera.

Tako „slijepa“ (očinska) ljubav vidi ono što želi vidjeti... Upravo i tu poruku odašilje sam otac otkrivajući ili najavljujući i svoja (očinska) očekivanja, a ona nisu mala. Stavljajući se u poziciju sinova branitelja, otac se duhovito, sa strane (sjedi babo pa ga ogovara), otvoreno i svjesno narugao sebi - svojoj slijepoj ljubavi - što za posljedicu ima zapravo davanje prava majci (što sina kara) pojačavajući njenu superiornost realnijeg i objektivnijeg roditelja. U teoriji govornih činova osoba koja je u poziciji da se brani, kao i ona koja na ovakav način štiti nekoga, u podređenom je položaju. Zato je majka posve superiorna čak i u svojoj popustljivosti: kara $i$ opet se $s^{\prime}$ sinom razgovarala... (Ili je i to, pošto je u uspavanki riječ u posjedu majke, tek samo još jedna puka želja majke/žene?!)

Uspavanka poručuje: Majki d'jete u ruži se našlo.., a ne „ocu dijete..."; i kaže još: majka Smaju pod đulom rodila...; spavaj, sine, rodila te majka,/ rodila te i ohranila te.../; majka sina u gori rodila...; nini, sine, ninala te majka...; majka sina u bešici lila... Pa i zahvala ide majci, ili - najprije majci:

-Golubica na babine došla

Donila joj pitu i pogaču

Pitu slatku i pogaču slanu

Nek to jide toga malog majka

Neka njemu bude više mlika... (,San...“, 25)

-oni idu Kevser vodi,

Da zafate hladne vode, 


\section{Da napoje mile majke,}

Mile majke i babajke... ( „Vjerski običaji...“, 185)

I muštuluk za lijepo djelo sina/djeteta nosi se majci najprije:

-daj muštuluk Anijina majko,

Anija ti hatmu učinio!

Majka daje biser i dukate,

Babo daje nebrojeno blago... (,San...“, 38)

\section{Ponavljanja}

Uspavanka je, na neki način, pjevni monolog majke/žene. Ona se obraća sinu/djetetu ne očekujući „odgovor“, zapravo dokida i svaku mogućnost govora - odgovora, osim da dijete zaspi. Time se mjeri efikasnost njena govora/uspavljivanja. Dijete je u poziciji da sluša žubor riječi i tonske modulacije; ono osjeća ritam, jačinu, visinu, zvučanje, ali sadržaj po pravilu ne razumije niti ga, konačno, treba razumjeti... Uspavanka na taj način ostvaruje i Jakobsonovu fatičku funkciju (pa ako uspavanka utihne i prestane prije nego što dijete zaspi učvrsti san, ono će se oglasiti često plačem jer je „kontakt“, tj. komunikacijski kanal prekinut prije vremena). Dijete kao percipijent na svoj način „dešifrira“ ono što čuje, jer je njemu, u uzrastu u kojem se uspavljuje, ostavljeno upravo da uspavanku primi sluhom, što znači da mu ostaju zvuk i zvučanje, odnosno konotacija, a ne (denotativno) značenje i smisao. Percipirajući uspavanku sluhom, njenim formalnim dijelom, planom izraza - rečeno Saussureovom terminologijom važnim mu se pokazuju artikulaciono-akustičke komponenate izraza, ritam, tempo, intonacija... ili tzv. vrednote govornog jezika, izraženo pojmovima P. Guberine. (Naučna istraživanja pokazala su da se čak $38 \%$ osjećaja izražava glasom, a tek $7 \%$ značenjima riječi, ostalih 55\% mimikom, posebno očima, up.: Škarić 2000:178).

Uspavanka je djelo izrazito emocionalno-ekspresivnog stila. $\mathrm{Na}$ emociji je utemeljeno njeno žanrovsko određenje, njen govorni izraz, tematska detaljizacija, kompoziciona struktura i dr.

Čin bajkovitog kantabilnog (pjevno izvedivog) uspavljivanja djeteta, zapravo nježnog i blagog nagovaranja da zaspi, da usni u potpunom je skladu s ujednačenim i usporenim ljuljanjem bešike ili ninanjem djeteta na nogama i u naručju: lijevo-desno, lijevo-desno... 
To je ujednačeni, monotoni ritam mehkog i laganog hoda. Zato bitan repertoar izražajnih sredstava uspavanke čine upravo višestruka ponavljanja i repeticija. Oni bitno određuju ritam uspavanki.

Ponavljanja u uspavankama ostvarena su na planu izraza, kao ponavljanja najčešće otvorenih slogova (u kojim često dominiraju završni vokali $i, u)$ i slogova u kojima dominiraju sonanti $(n, m$ i $l)$ : $\mathrm{Ni}$-ni, bu-bi, ni-kli-si-nu- zu-bi , Ni-ni-, bu-bi-, po-ni-kli- ti-zu-bi (,Bošnjačke...“, 42 i 48)

Pjesničku vrijednost vezujemo za stupanj oneobičavanja ili očuđenja. U odnosu na običnu učestalost ovih glasova, u uspavankama su, kao višestruko ponovljeni, oneobičeni. Efekat ovakvih zvukovnih, glasovnih ponavljanja na fonetskom nivou (na planu izraza) pojačavaju ponavljanja jedinica na višim jezičkim nivoima.

Ponavljanje se temelji na takvom razvijanju uspavanke da svaki korak naprijed znači u isto vrijeme i korak nazad: nešto što će se opet pojaviti, da bi se uopće percipiralo kao ponovljeno, mora ostati upamćeno. Zato je ovdje riječ o svojevrsnim retardacijama, koje usporavaju ritam, što je pak dominatno obilježje uspavanke. Up: epizeuksična ponavljanja (po notnom zapisu, tj. stvarnoj izvedbi):

\section{-Nina, buba, nina, buba, rodila te majka}

Rodila te, rodila te i pogojila te,

Čelica te, čelica te medom zadojila,

Bila vila, bila vila tebi eba bila... („Bošnjačke...“, 31)

Ponavljanja pojačavaju strukturnu koherentnost uspavanke, kao što utiču i na njen ritam i melodijsku liniju. Ponavljanja na fonetskom nivou pojačavaju određene zvučne efekte, a kombiniraju se i sa ponavljanjima na leksičkom nivou.

Mogu se javiti kao ponavlje iste riječi - kad se ponavlja isti glasovni sklop, ali u različitim pozicijama (na početku - anaforska, na kraju - epiforska, na početku i na kraju - simplohska, na kraju jednog stiha i na početku drugog - anadiploski) itd. Posebno su česte figura etimologije i(li) paregmenon (v.: Zima 1988:283), kao ponavljanje riječi istog korijena:

-Majka sina u bešici lila,

beša ti se na moru kovala („Bošnjačke...“, 40) 
-Tvoja beša na moru kovana,

Kovale je age i hadžije (,San....", 24)

-Treći meće sjajno ogledalo

Ko se nina da se oglediva (,San...“, 21)

- San usnilo u sanku vidilo („,San...“, 39)

-Tvoja beša zlatom okovana,

tvoja beša na moru kovana;

tri kovača tvoju bešu kuju... (,San...“, 50)

i poliptoton (ponavljanje iste riječi u različitim oblicima, posebno padežnim, v.: Zima 1988:282):

-Ninaj, sine, u varakli beši,

beša ti je na moru građena (,San...“, 21)

-Majka Smaju pod đulom rodila

Đul se truni moga sina budi (,San...“, 22)

-U kabur nas zatvoriti.

U kaburu mračna noćca (,, San...“, 51)

-oni idu Kevser-vodi

da zafate hladne vode (,San...", 23)

-Nini, nini ko u svojoj beši!

Tvoja beša na moru kovana („San...“, 24)

-Majka sina u gori rodila,

u gorici na zelenoj travi (,San...“, 25)

-Majka tebe u šumi rodila,

U šumici ovce čuvajući (,San...“,46)

-Majka sina u ruži rodila,

Ružica ga na list dočekala (,, San...“, 49) 
Mehanizam ponavljanja u uspavankama, koji smo ovdje čini se tek dotaknuli, važan je za i razumijevanje folklornog kao i poetskog teksta uopće.

\section{Uspavanka ilahija - ilahija uspavanka}

Uspavanka je poznata u svjetskoj usmenoj i pisanoj književnosti, kako ističe Hanifa Krnjević, i vrlo njegovana u bošnjačkoj tradiciji ${ }^{17}$.

Dvije ilahije bosanske alhamijado književnosti bile su vrlo omiljene uspavanke u bh. tradiciji. To su „Hazreti Fatima kad bi šikala' ${ }^{186 ، ~(s ̌ i k a l a ~ ' l j u l j a l a ', ~ ' u s ̌ u s ̌ k i v a l a ') ~ M u h a m e d a ~ R u s ̌ d i j a ~(p j e s n i c ̌ k i ~}$ pseudonim Muharemage Dizdarevića, rođ. u Trebinju 1825) i ilahija „Kad ja pođoh u džamiju“ nepoznatog autora. One su se pjevale/učile djeci uz bešiku (up. M. Memija ${ }^{19}$, A. Aličićc ${ }^{20}$ ). Posebno je bila popularna ova druga ilahija, koja je doživjela mnoge verzije. Jedna od njih ovako počinje:

${ }^{17}$ Uspavanke su u bh. književnosti pisali mnogi pjesnici. U jednom vremenu bile su vrlo popularne uspavanke Šukrije Pandže (Tašun, tašun, tanana...) i Nasihe Kapidžić-Hadžić (Tiha pjesmo, išarana/ paunovim sjajnim krilom/ paučinom izatkana/ opšivena žutom svilom/ tiša nego voda plava/ uspavaj mi malog mrava...).

${ }^{18}$ Ona ovako ide:

Hazreti Fatima kad bi šikala

Hasan i Husejna kad bi ljuljala,

Uz bešiku to bi ona učila:

„U džennetu od mlijeka vrelo ima,

Od Meke je do Jemena dolina,

Od Safe je do Adena širina.

Rad Hasana i Husejna i oca

Hazret Alije Bog je dao i vama. "

Navedeno prema: Dr. Abdurahman Nametak, „Hrestomatija bošnjačke alhamijado književnosti“", Svjetlost, Sarajevo, 1981, 87.

${ }^{19}$ M. Memija navodi da je „Hazreti Fatima kad bi šikala“ uspavanka, a da je "Kad ja pođoh“ ilahija pjevana djeci pri uspavljivanju, v: Minaka Memija, „Ehli-bejt u Bosni i Hercegovini“", zb. Radova Naučnoistraživačkog instituta Ibn Sina, v.: htt://ibnsina.net.

${ }^{20}$ A. Aličić navodi da je ilahiju „Kad ja pojdo u džamiju“ slušao u Doboju i da je, uz pripjev „La ilahe illella“ nakon svakog stiha, pjevana djeci uz bešiku, v.: Aličić Ahmed, „Kad ja pojdo u džamiju“, Novi behar, IX/1935-36, 4/5, str. 55 (nav. prema: Zbornik alhamijado književnoti, prir. Muhamed Huković, Preporod, Sarajvo, 1997, 203). 
Kad ja pođoh u džamiju -La ilahe illella

U džamiju klanjat sabah - La ilahe illellah

srete mene naš Pejgamber - La ilahe illellah... ${ }^{21}$

21 „Mevludi, ilahije, kaisde“, Kaj, Zagreb, 1994, 94. Ovu ilahiju uvrštavaju među usmene uspavake obično od druge strofe:

Ovaj svijet bijel cvijet

ovaj insan bijel behar

i behar će opadati

$i$ insan će pomrijeti

Svakome će edžel doći

i insanku i hajvanku

i tičici u gorici

$i$ ribici $u$ vodici

crnu mravu na zemljici -

i njemu će vakat doći...

kako je nalazimo u zb. „San u bešu, uroci pod bešu“ (str. 51) i „Pod beharom moje janje spava“" (str. 20). U jednoj drugoj varijanti ova strofa glasi:

Ovaj svijet - jedan cvijet - La ilahe illellah

insan ti je kao behar-La ilahe illellah

puhne vjetar, ode behar - La ilahe illellah

Svi ćemo mi pomrijeti - La ilahe illellah

u kabur se zatvoriti - La ilahe illellah..

(up. pjesmu pod naslovom „Kad ja pođoh u džamiju“, u zb. „Mevludi, ilahije, kaside“, 1994, 94). Kao dio ilalahije „Ovi svit cvit“" nepoznatog zapisivača bosanske alhamijado književnosti u „Hrestomatiji...“ Abdurahmana Nametka ovi stihovi navedeni su u ikavici i u nešto drugačijoj varijanti, što potvrđuje popularnost pjesme u narodu i rasprostranjenost po Bosni:

Ovi svit cvit la ilahe illella

I tičici i gorici

la ilahe illellah

I ribici $i$ vodici

la ilahe illellah

I svakome na svitu la ilahe illellah

Ovi insan ka i behar la ilahe illellah

dunu ejjam, diže behar la ilahe illellah

doće zeman umirati la ilahe illellah... (str. 84)

Ilahija je u „Hrestomatiju...“ unesena onako kako je transliterirana ili transliteriranoredigirana u Akademiji nauka BiH (v.: Nametak, 1981,45). Ilahije su se inače u nas često prepisivale, učile napamet $\mathrm{i}$ usmeno prenosile $\mathrm{i}$ pri tome naravno ponešto mijenjale, kao i druge usmene, narodne pjesme (v. Nametak, 1981,23). Ovu je prvi put zabilježio nepoznati zapisivač 1179. h. g. (1766/7). Kao omiljena, doživjela je mnoge preinake, dorade, verzije. Autorom jedne (štampana 1875) smatra se Mostarlija Omer-ef. Humo a započinje ovako:

Kad ja pođo u džamiju, susrete me naš pejgamber, 
Kad se u zbirkama pjesma navodi kao uspavanka, po pravilu se ovi početni stihovi ispuštaju kao i pripjev „La ilahe illella“ (up.: Kajan 1996, Efendić 2007, Musabegović 1997).

Istraživači naše usmene književnosti naglašavaju utjecaj usmene - na alhamijado književnost. Poređenje alhamijado uspavanki $\mathrm{i}$ onih koje su se javile u usmenoj tradiciji kao njihove varijante ide $u$ prilog uvjerenju o njihovom međusobnom prožimanju i utjecaju.

\section{Kontinuitet}

Kao folklorna djela, uspavanke su se prenosile usmeno, s generacije na generaciju. Svaka je generacija na neki način unosila preinake u tekst, prema vlastitom iskustvu i pamćenju naprosto zato što nije lahko doslovno zapamtiti i prenijeti tekst koji se jednom čuje a dalje usmeno prenosi. Istina, lakšem pamćenju doprinosi to što se pjeva, tj. njen napjev i stihovna forma (metar, ritam itd.) po sebi jake mnemoničke moći.

Promjene teksta, po pravilu, nisu bile velike. Zadržavale su se u nasijeđenom tekstu i dalje se, kolektivnim pamćenjem, prenosile narednim generacijama onako kako se prenosi žanr ili palimpsest: tekst se neprestano obnavljao s gneracije na generaciju jer je svaka upisivala svoj trag osiguravajući kontinuitet i jedinstvo teksta. Uspavanka je tako uvijek novi, a u isto vrijeme i stari tekst. Svakoj

di me srete, tu mi reče:

„Ovaj svijet kano cvijet,

ovi insan bijel behar,

puhnu ejan, spade behar.

Svačemu će feleć doći,

i insanu i hajvanu,

i tičici u gorici,

i ribici u vodici,

i nama će mrijet doći,

u mezar se zatvoriti,

u mezaru nejma pendžer

da ja gledam po Dženetu...

Poznata je pod popularnim nazivom „Dženetska ilahija“. Dio je prve štamane knjige arebicom na bosanskom jeziku Omera Hume. Naveli smo je prema „Zborniku alhamijado književnosti““ (priredio M. Huković 1997, str. 203), gdje se nalazi i ilahija naslovljena kao „Ovi svit cvit“, koju razumijevamo kao vrlo blisku varijantu ove „Đenetske ilahije“ (započinju drugačije i u drugom dijelu prilično se razlikuju). 
novoj „varijanti“ predložak je prethodna uspavanka, pa stoga funkcionira kao svojevrsna metauspavanka: pjeva ono što je zapamtila dodajući ponešto novo iz stvarnog svijeta u kojem se našla, a to se, obično, tiče ličnog imena djeteta itd. Kao ilustraciju navest ćemo stihove nekoliko uspavanki:

(A).

Nini, nini, puna mi te beša,

o godini još punija bila...

(B)

Nini, sine, puna mi te beša,

dogodine još punija bila...

(C)

Alju, ljulju, lju-lju, otjeraše Sulju,

Ani, nini, ni-ni, otjeraše Drini.

(D)

Nini, nini, oćeraše Drini,

Ljulju, ljulju, oćeraše Sulju.

„Uroke ti voda odnijela,

U pobusku djecu donijela“.

Stihovi uspavanki (A) i (D) zabilježeni su kao jednoglasno pjevanje $u z$ bešu iz Bosanskog Podrinja u zb. O.Golemovića „Narodna muzika Podrinja“ (Golemović 1987:534). Stihovi ove druge uspavanke (D) zabilježeni su u Kravici, kod Srebrnice (prema pjevanju A. Šabića, r. 1966, M. Omanović, r. 1963. i E. Šabić, r. 1954, up.: Golemović 1987:128, pjesma 284). Od preostalih dviju uspavanki jedna (B) je iz zb. C. Rihtmana „Dječije pjesme“ (Rihtman 1974:161) a druga (C) iz zb. N. Efendić „San u bešu, a nesan pod bešu“ (Efendić 2007:11) - po vlastitom sjećanju mlade autorice izbora N. Efendić (r. u Srebrenici). Vjerovatno su stihovi (C) i (D) varijante iste uspavanke. 


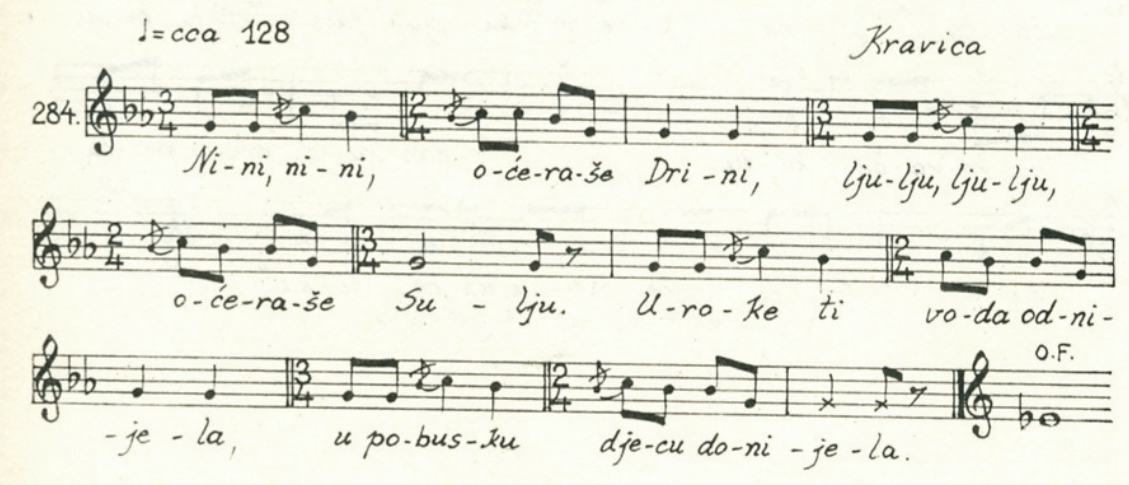

Notni zapis uspavanke iz poglavlja „Uspavanke - pjevanje 'uz bešiku““ (O. Golemović, „Narodna muzika Podrinja“, 1987)

Na kraju, dodat ćemo i ovo: usmena bošnjačka uspavanka nastajala je u uvjetima dominantno patrijarhalnih obrazaca ponašanja kao rafinirana ženska pjesma, topli govor/pjevanje/učenje majke/žene sinu/djetetu, ali je pokazala značajnu vitalnost održavši se zapravo do danas. Dvije knjige uspavanki, prva u izboru Jasmine Musabegović „Bošnjačke uspavanke“ (1997) a druga Nirhe Efendić „San u bešu, uroci pod bešu“ (2007), potakle su temu koja nam se čini neiscrpnom jer nije ni dotaknuto sve bogatstvo figura i tropa (hiperbola, sinkopa, prolepisi, paragoga, afereza...), mnogi arhaizmi i dijalektizmi, simbolika broja tri (tri kujundžije kuju bešu), izrazito odsustvo glagola, ekspresivnost derivacionih morfema u uspvankama (deminucijskih i augmentacijskih) itd.

I za uspavanke čini se da vrijedi ono što je George Moline rekao za stilistiku: da je vila za koju su neki vjerovali da je umrla, dok su je drugi toliko grlili da je gubila svijest... 
1. Antologija usmene priče BiH /priredile Dženana i Lada Buturović/, Svjetlost, Sarajevo, 1997, 263

2. Bošnjačke uspavanke/priredila Jasmina Musabegović/, Preporod, Sarajevo, 1997, 57

3. Čolaković, Enver, Jedinac, BNZH, Zagreb, 2005.

4. Golemović, Dr. Dimitrije O., Narodna muzika Podrinja, Drugari, Sarajevo, 1987, 90 i 534-535

5. Hangi, Anton, Die Moslim's in Bosnien-Hercegovina, Druck und Verlag von Danie A. Kajon, Sarajevo, 1907, 233-250

6. Hrvatske narodne ženske pjesme (muslimanska) /sabrao i uredio Mehmed-Dželalluddin Kurt/, Hrvatska dionička tiskarna, Mostar, 1902, 203

7. Kadić, Rešad, Pobožne pjesme bosanskohercegovačkih muslimana. - U knjizi: Mulahalilović, Enver, Vjerski običaji muslimana u Bosni i Hercegovini (II dopunjeno izdanje), ElKalem, Sarajevo, 1989, 184-186

8. Mevludi, ilahije, kaside /priredio I. Kajan/, Kaj, Zagreb,1994, 155

9. Pod beharom moje janje spava /sastavio I. Kajan/, Preporod, Zagreb, 1996, 17-24

10. Rihtman, Cvjetko, Dječije pjesme, Zbornik napjeva narodnih pjesama Bosne i Hercegovine, ANBiH, Sarajevo, 1974.

11. San u bešu, uroci pod bešu, 33 bošnjačke uspavanke /odabrala i priredila Nirha Efendić/, BZK Preporod, Općinsko društvo Centar Sarajevo, BZK Preporod, Općinsko društvo Vogoća, 2007, 107

12. Zbornik alhamijado književnosti /odabrao i priredio dr. Muhamed Huković/, Preporod, Sarajevo, 1997, 87-240

13. Živković, Blagoje Ž. Uvođenje u književnost $i$ pismenost, drugo izdanje, Kulturni centar, Novi Sad, 1969, 20

\section{Literatura}

1. Bourdieu (1992) Pierre Bourdieu, Što znači govoriti, Naprijed, Zagreb

2. Butler (2000) Judith Butler, Nevolje s rodom, Zagreb 
3. Hadžiefendić (1984) Remzija Hadžiefendić, Turcizmi u funkciji imenovanja likova u „Dervišu $i$ smri“ “ $i$,Na Drini ćuprija“, Književni jezik, XIII, br. 4, Institut za jezik, Srajevo, 199-217

4. Hadžiefendić (1990) Remzija Hadžiefendić, Imenovanje likova turcizmima u „Dervišu i smrti“, Radovi Filozofskog fakulteta u Sarajevu, knj. XI, Sarajevo, 41-79

5. Iser (1976) W. Iser, Der Akt des Lesens, Munchen.

6. Jahić (1999) Dževad Jahić, Školski rječnik bosanskog jezika, Ljiljan, Biblioteka Linguos, Sarajevo

7. Jakobson (1966) Roman Jakobson, Lingvistika $i$ poetika, Nolit, Beograd

8. Kirdin (1978) N. I. Kidrin, Obščee i osobennoe v pesnnom fol'klore vostočny $i$ zapadnyh Slavjan perioda vtoroj mirovoj vojny. - U knjizi: Istorija, kul'tura, etnografija $i$ folklor slavjanskih narodov, Izdatel'stvo „Nauka“, Moskva

9. Klajn (1985) Ivan Klajn, O funkciji i prirodi zamenica, Institut za srpskohrvatski jezik, Beograd

10. Kristeva (1979) Julija Kristeva, Prelaženje znakova, Svjetlost, Sarajevo

11. Krnjević (1973) Hatidža Krnjević, O usmenim (narodnim) pjesmama /predgovor/. - U knjizi: Narodne pjesme, „Veselin Masleša", Sarajevo

12. Krnjević (1998) Hatidža Krnjević, Urok, kletva i snoviđenje u balad. - U: Bošnjačka književnost u književnoj kritici, knj. II, Alef, Sarajevo.

13. Kurtene (1905) Boduen de Kurtene, Ob odnoj iz storon postepennogo čelovečenija jazyka v oblasti proiznošenija $v$ svjazi s antropologiji. - U: Predrag Piper, Lingvistički spisi, Književna zajednica Novog Sada, Novi Sad, 1988.

14. Memija, Minka, Ehli-bejt u Bosni i Hercgovini, Radovi Naučnoistraživačkog instituta Ibn-Sina, v.: http://ibn-sina.net/

15. Nametak (1981) Abdurahman Nametak, Hrestomatija bosanske alhamijado književnosti, Svjetlost, Sarajevo

16. Nazečić (1998) Salko Nazečić, Junačke narodne pjesme. - U: Bošnjačka književnost u književnoj kritici, knj. II, Alef, Sarajevo 
17. Novosel (2004) Branka Novosel, Prevođenje kroz prizmu lingvistike $i$ pragmalingvističkih spoznaja, HDZTP, „Prevoditelj“, 80-81.

18. Škaljić (1989) Abdulah Škaljić, Turcizmi u srpskohrvatskom jeziku, Svjetlost, Sarajevo

19. Škarić (1974) Ivo Škarić, Nastanak dječjeg govora, Zavod za fonetiku, Zagreb

20. Škarić (2000) Ivo Škarić, Temeljci suvremenog govorništva, Školska knjiga, Zagreb

21. Todorov (1986) Cvetan Todorov, Poetika, „FilipVišnjič“, Zavod za izdavačku delatnost, Beograd

22. Traugott i Pratt (1980) E.C. Traugott i M.L.Pratt, Linguistics for students of Literature. - U knizi: Branka Novosel, Prevođenje kroz prizmu lingvistike teksta i pragmalingvističkih spoznaja, HDZTP, Prevoditelj, 80-81, 2004

23. Uspenski (1979) B.A.Uspenski, Poetika kompozicije $i$ semiotika ikone, Nolit, Beograd

24. Vuletić (1986) Branko Vuletić, Sintaksa krika, Izdavački centar Rijeka, Rijeka

25. Zima (1988) Luka Zima, Figure u našem narodnom pjesništvu $s$ njihovom teorijom /pretisak izd. JAZU iz 1880/, Globus, Biblioteka Theoria universalis, Zagreb 


\section{PROF. REMZIJA HADŽIEFENDIĆ-PARIĆ, P.H.D.}

\section{POETICS OF BOSNIAN FOLK LULLABIES}

\section{SUMMARY}

We are talking about traditionally cultivated verbal literary genre of Bosnian literature - cantabile, performed by singing / reading in its real functioning like some other poetical genres (e.g. svdalinka - oriental style love song). Lullaby is therefore, double coded: it has «liberto» (text that belongs to literary scholarship code) and performance/reading (which belongs to musical code and includes various repetitions, often lost while noting down a lullaby). Our analysis deals with the first code and the procedure... Lullaby is talk of mother to son (mother talks to her son) or wider-female talk, since it was performed by mothers/women. Mother/woman talks about herself, so lullabies are also viewed from this aspect. 


\section{الأستاذة الدكتورة رمزية حاج أفندينش - باريتش \\ الشعر في أغنية النوم الشعبية لدى البشاندانة \\ الملخص}

إنه عبارة عن نوع من الأدب الثفوي الذي يعتتى به تقليدياً في أدب البشانقة. لقد كان

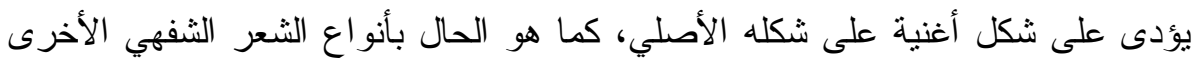

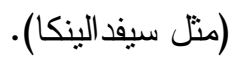

أغنية النوم، إذاً، لها مدونتان: لها "ليبريتو" أي النص التابع للمدونة الأدبية الفنية،

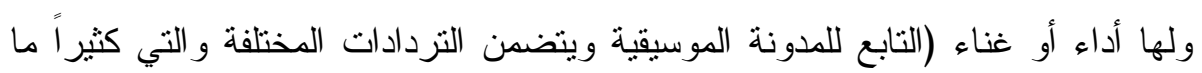
كان يغفل عنها خلال تدوين أغاني النوم). التحليل في هذا البحث يتتاول الخطة الأولى و الخطو ات. أغنية النوم هي قول الأم لوليدها (أي الوالدة تكلم ولبيدها) أو هو بشكل ولاولى عام كلام

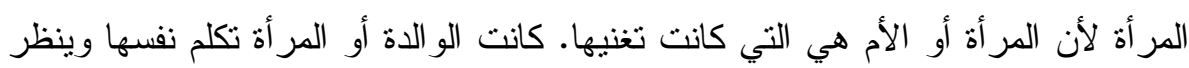

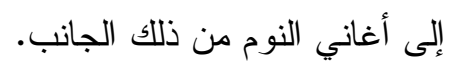

